\title{
The need for new strategies to combat the epidemic of smoking-related harm
}

\author{
Ron Borland
}

\section{Correspondence to}

Ron Borland, Nigel Gray Distinguished Fellow in Cancer Prevention, The Cancer Council Victoria, 1 Rathdowne Street, Carlton VIC 3053, Australia; ron.borland@cancervic.org.au

Received 16 March 2011 Accepted 2 August 2011
In 2003, I published a paper in this journal ${ }^{1}$ arguing for the consideration of a regulated market model (RMM) for tobacco, a mechanism by which the mass marketing, but not manufacture, of tobacco products would be taken out of the hands of forprofit companies and given to an agency with a harm reduction charter. This agency would determine what was sold and under what conditions, and retailers would effectively become its agents.

In that time, nobody has identified any conceptual flaw in the model. The arguments against it are that it would not happen (true if no-one argues for it), that regulation is anathema to governments, that it would put government in the embarrassing position of selling harmful products (the paper suggested government control of the agency but that is not essential), that the proposal lacks advocacy appeal as it is a mechanism rather than a solution, and that to pursue it would divert limited energy from more conventional solutions. ${ }^{2}$ This critique assumes that we will be able to achieve everything we want with the continuation and expansion of current strategies, something I doubt. ${ }^{3} 4$

The paper had some effects. It was a stimulus to Callard and colleagues ${ }^{5}$ to develop a model which would operate outside of government control and was among the first of what is now a steady stream of thinking about endgame solutions. ${ }^{7-12}$ The big questions are whether radical solutions are required for the tobacco problem and whether fundamental reform of the tobacco industry should be part of it.

Since 2003, there has been a lot of progress in tobacco control, with the Framework Convention on Tobacco Control (FCTC) coming into force. It has galvanised action from many governments, including some that had previously ignored the problem. Many have been pleasantly surprised at the strength, both of the convention itself and of some of the guidelines that the parties have adopted.

Some countries are now moving beyond what the FCTC mandates. Australia is legislating to institute plain packaging, better described as standard packaging as brand names will still be allowed (something only a RMM could remove) along with variant descriptors and it will expand the graphic health warnings. There will remain opportunities for the industry to exploit any areas of difference to promote their products, as they are obliged to do by their shareholders. While companies still compete in the market, we need to watch them carefully to ensure that competition does not result in them adding value to their products, potentially leading to increased use.

The legislation to empower the US Food and Drug Administration to regulate tobacco is another extremely important advance. However, I fear progress will be slow and costly because of the inherently antagonistic model of manufacturers resisting what regulators try to control, including by endless litigation, except where manufacturers see a commercial advantage, either absolute or relative to their competitors in the new rules, something that will not stop the others litigating. A RMM would greatly speed up progress to achieving less-harmful products.

That nobody has seriously tried to implement a RMM is disappointing but not surprising. More recently, colleagues and I have attempted to analyse tobacco control more systematically, ${ }^{13}$ approaching the problem from an open systems perspective and highlighting the inter-related roles of the tobacco industry and tobacco control forces. We then ${ }^{14}$ discussed why a systems analysis was insufficient for a solution to emerge and used Actor Network theory to describe the essentially politically contested processes that are needed for fundamental systems change.

Progress since 2003 is likely to have had mixed effects on the need to focus on transformation of the industry. Some of the above-mentioned barriers might be dissipating; there is now greater understanding of the power and limitations of unconstrained free-market forces and the need to sometimes curtail them, including consideration of clever regulation (albeit still limited action to implement such approaches). Tobacco is a great example of how the free-market cannot operate effectively when there is not a solution around making the product less harmful while still being consumer acceptable. In the absence of sufficiently harm-reduced products that society is prepared to accept long term, a free-market must be problematic.

Every tobacco control conference I attend is full of stories of industry calumny and how they are undercutting our efforts and trying to expand their markets. The FCTC has strict guidelines around Article 5.3 (dealing with the tobacco industry), which makes tobacco companies virtual pariahs. All agree tobacco companies are part of the problem, but few ask if they need to be part of the solution. Do we really need to have them around at all (at least in their present form)? If there is no viable mechanism for a free-market solution to the tobacco problem, would it not be better public policy to remove them from their position controlling the market.

More fundamental to resistance to a RMM, at least within sections of the tobacco control movement, is that it implies an ongoing demand for tobacco (else why have a special agency to supply it?) and this seems to be the spectre of a harm reduction agenda, which for some 
challenges fundamental values, ${ }^{15}$ while for others, who believe that we are progressing well, it is unnecessary. One of the RMM's strengths is that it could be a responsible supplier of harm-reduced nicotine products, doing so in a way that would reassure many who are concerned with the likely adverse effects if tobacco companies could market still-harmful products with only the limited constraints that are possible in some markets (eg, USA).

Notwithstanding the progress that has been made in some countries, ${ }^{16}$ there is no sign that tobacco use will disappear any time soon. Even in the most successful countries using the most optimistic extrapolations, unacceptably high levels of tobacco use are likely to be around for at least 20 years. This is not a platform for complacency, although it is a platform for continuing to do as much of what we know works as possible. If tobacco is a large enough problem to have an international treaty to control it, we should be doing all we can to reduce harmful use. This means we should be moving as rapidly as possible to eliminate the widespread use of smoked tobacco. Anything and everything that could help achieve this goal should be actively considered. This requires a search for new solutions, a research agenda to answer the uncertainties that can be addressed about them and development of implementation frameworks that minimise risks. The RMM is a mechanism that can both minimise the risks and make some forms of action easier and quicker to implement. It is a tool for aligning the major forces involved in the tobacco market around a common goal of trying to eliminate harmful use.

If we want some inspiration as to where our thinking and action should be moving, we should be looking to New Zealand where visionary thinking has propelled their government to at least canvas possibilities for the elimination of smoked tobacco (http://www.sfc.org.nz/). Unless we can be certain that our current strategies will be enough to solve the problem, we should be looking for new solutions and testing them, so if and when we decide we need to do more, we are ready to act.
Funding Cancer Council Victoria, Australia.

Competing interests None.

Provenance and peer review Commissioned; externally peer reviewed.

\section{REFERENCES}

1. Borland R. A strategy for controlling the marketing of tobacco products: a regulated market model. Tob Control 2003;12:374-82.

2. Liberman J. The future of tobacco regulation: a response to a proposal for fundamental institutional change. Tob Control 2006;15:333-8.

3. Borland R. Taming the tigers: the case for controlling the tobacco market. Addiction 2004;99:529-31.

4. Borland R. Why not seek clever regulation? Tob Control 2006;15:339-40.

5. Callard C, Thompson D, Collishaw N. Curing the Addiction to Profits: A Supply-Side Approach to Phasing Out Tobacco. Ottawa: Canadian Centre for Policy Alternatives, 2005.

6. Callard C, Thompson D, Collishaw N. Transforming the tobacco market: why the supply of cigarettes should be transferred from for-profit corporations to non-profit enterprises with a public health mandate. Tob Control 2005:14:278-83.

7. Daynard RA. Doing the unthinkable (and saving millions of lives). Tob Control 2009;18:2-3.

8. Gartner C. McNeill A. Options for global tobacco control beyond the Framework Convention in Tobacco Control. Addiction 2010;105:1-3.

9. Gilmore AB, Branston JR, Sweanor D. The case for OFSMOKE: how tobacco price regulation is needed to promote the health of markets, government revenue and the public. Tob Control 2010;19:423-30.

10. Hall W, West R. Thinking about the unthinkable: a de facto prohibition on smoked tobacco products. Addiction 2008;103:873-4.

11. Malone RE. Imagining things otherwise: new endgame ideas for tobacco control Tob Control 2010:19:349-50.

12. Thomson G, Wilson N, Blakely T, et al. Ending appreciable tobacco use in a nation: using a sinking lid on supply. Tob Control 2010;19:431-5.

13. Borland R, Young D, Coghill K, et al. The tobacco use management system: analyzing tobacco control from a systems perspective. Am J Public Health 2010;100:1229-36

14. Young D, Borland R, Coghill K. An actor-network theory analysis of policy innovation for smoke-free places: understanding change in complex systems. Am J Public Health 2010:100:1208-17.

15. Alderman J, Dollar KM, Kozlowski LT. Understanding the origins of anger, contempt, and disgust in public health policy disputes: applying moral psychology to harm reduction debates. J Public Health Pol 2010;31:1-16.

16. Pierce JP, Messer K, White MM, et al. Forty years of faster decline in cigarette smoking in California explains current lower lung cancer rates. Cancer Epidem Bioma 2010:19:2801-10. 